AFRIKA FOCUS - Volume 3I, Nr. 2, 20I8 - pp. I49-163

\title{
MEDIATING MATONGE: RELOCATIONS OF BELGIAN POSTCOLONIALITY IN FOUR FILMS
}

\author{
Karel Arnaut \\ Interculturalism, Migration and Minorities Research Centre, KU Leuven, Belgium \\ Former vice-president of the Ghent Africa Platform (GAP) \\ In this paper I look at the Matonge neighbourhood of Brussels as a locus of postcolonial and diasporic \\ imagination and activism by different groups and individuals most notably people who identify as Af- \\ ricans, Belgians with African roots, or 'Black' in Belgium. Within a longer historical narrative that starts \\ in the late $19^{\text {th }}$ century, I focus on the period beginning in the late 1980s when new migrational flows \\ from Africa and other southern countries into Brussels make the Matonge quarter increasingly visible \\ in an otherwise hesitantly globalizing Belgian/European metropolis. This issue is taken up by several \\ filmmakers who, over the last thirty years, have situated their critiques of the Belgian postcolonial \\ condition in 'Matonge'. In this paper I briefly present four of these films in order to illustrate the ways \\ in which 'Matonge' features in changing discourses concerning inequality, cultural affirmation, and \\ diasporic activism.
}

KEYWORDS: MATONGE, BRUSSELS, POSTCOLONIAL CONDITION, MEDIA AND MEDIATION

\section{Introduction}

In this paper I aim to present the city quarter called Matonge in Brussels as a locus of postcolonial diasporic imagination and activism in the fifteen years following the early

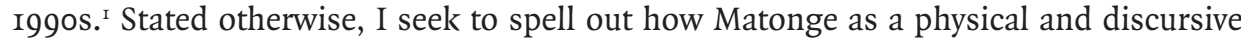
place has been reimagined, renegotiated or reconstructed in relation with the changing ways in which larger-scale entities such as Ixelles, Brussels Capital Region or Belgium have been decolonising themselves. By 'decolonising' I mean reworking their postcolonial condition, staging their migration-driven cultural diversity as well as the predicament of their migrant and diasporic communities, more particularly the sub-Saharan ones. More precisely, I will examine a number of films that were produced between the early I990s and the mid-2000s, mostly documentaries with the exception of one fiction

This article was first presented as a paper at the African Perspectives Conference (6-8/12/2007) at TU Deft (The Netherlands). Since then it has led a public life on the internet but was never formally published. While transforming it into a paper, I have not tried to completely erase the style of oral presentation of the paper. Neither have I tried to update the paper. Matonge surely continues to be mediated in novel ways and continues to feature in contemporary relocations and reworkings of Belgian postcoloniality. These would deserve a profound description and analysis but are entirely beyond the scope of this article. Nevertheless I have no knowledge of post 2006 films that focus on Matonge to the degree that the four films presented here do. 


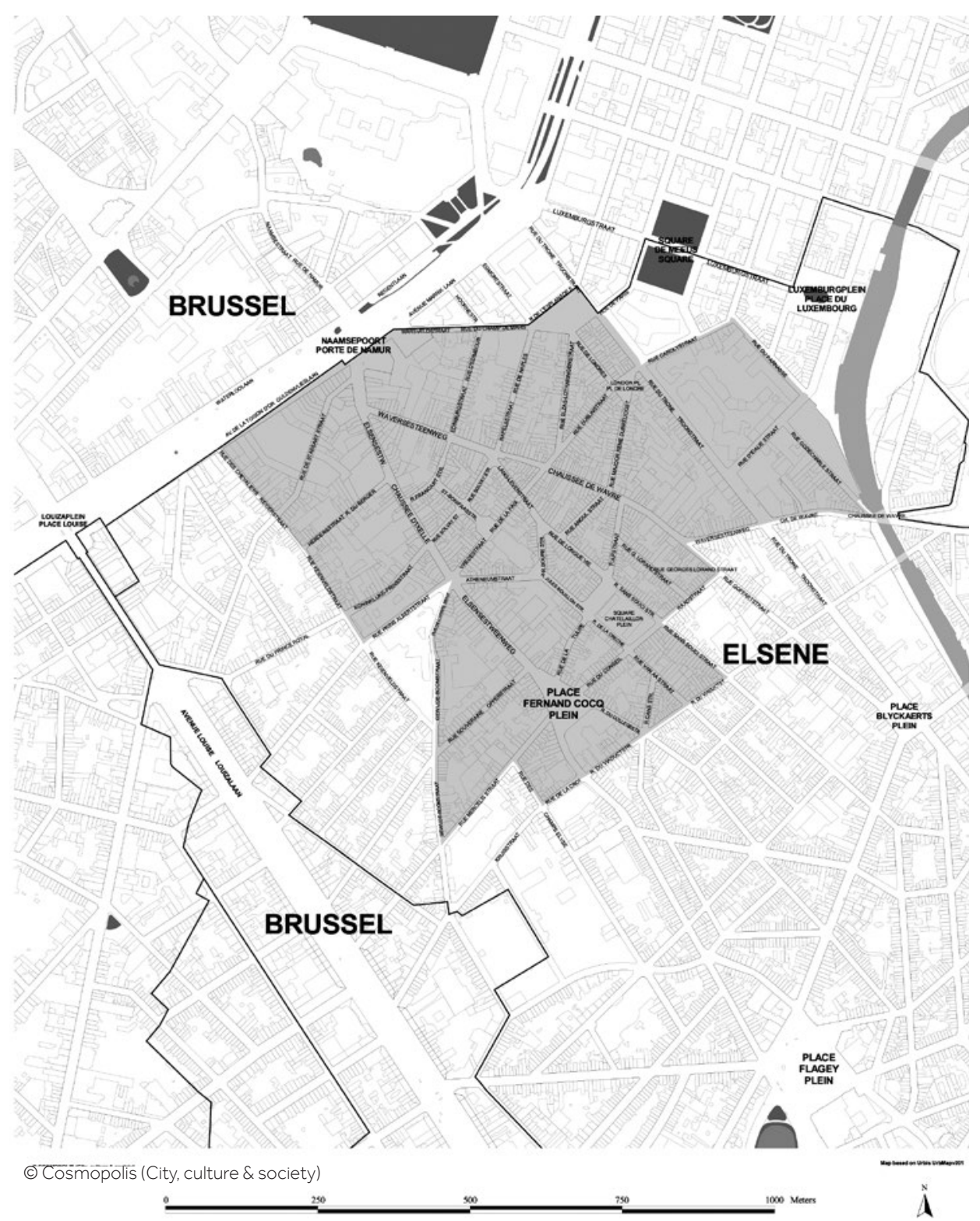

film. In these films 'Matonge' appears as a place which exemplifies changing discourses of inequality, cultural affirmation, and diasporic activism with respect to Africans and/ or 'blacks'.

Matonge is part of the commune of Ixelles and located in the south-eastern part of Brussels, just outside the old city centre, behind the Porte de Namur, about five hundred me- 
ters from the royal palace and in between two upmarket zones: the European 'Leopold' quarter and the Avenue Louise. Customarily, the shopping mall Gallérie d'Ixelles is considered to be the (hidden) heart of Matonge, while the adjacent Chaussée de Wavre and the traffic-free section of the street Longue-Vie (Langlevenstraat) are now seen as the city quarter's main arteries.

'Matonge' as a name for an urban neighbourhood is a postcolonial phenomenon in itself. The name emerged in Brussels shortly after it had been introduced to rename the Camp Renkin neighbourhood in the Kalamu commune of Kinshasa (then Zaire). Under Mobutu's zairisation programme of the early I970s the colonial label Camp Renkin - named after Jules Renkin, the first Belgian Minister of Colonies (I908 - I9I8) - was replaced by 'Matonge', the name of a local herb. Within years, 'Matonge' made its appearance in the Porte de Namur neighbourhood as the name of a bar. In the course of the Ig8os this name was increasingly popularized to indicate the "the focal point of Kinshasa's diasporic mirror [...] both a simulacrum of Kinshasa and a reinvention of Brussels" (De Boeck 2012 : 6I; see also Shungu I986) a meaning that continues today.

Films are not the only media formats in which Matonge has been represented. The painting "Matonge-Ixelles: Porte de Namur - Porte de l'Amour" by Cheri Samba, is certainly one of the most well-known representations of Matonge. Until the fall of 2007 - and after an interval of several years - a photographic blow-up of the painting measuring 15 by 12 meters decorated the façade of a department store at 'the entrance of Matonge' near the Porte de Namur. Mounted in 2002 this gigantic painting could be seen mediating Matonge to itself: its residents and shopkeepers, café owners and travel agents, as well as to its many regular and occasional visitors. Moreover, given the public-private partnership which made this possible, this canvas also epitomized the combination of official recognition of Matonge and its commercial attractiveness.

Similar to Cheri Samba's intervention in Brussels' public space, the four films can be seen as mediating 'Matonge' in different ways. For starters, the films present images of the urban neighbourhood, while they capture, quote, refract or contest existing (often stereotypical if not downright racist) representations or imagery of Matonge. Also the filmmakers, their collaborators and informants, their official supporters and their financers function as mediators in providing and circulating new representations of Matonge.

\section{Four movies}

\section{Sango Nini, quoi de neuf? (Anne Deligne \& Daniel De Valck, 1991)}

Anne Deligne \& Daniel De Valck are both Brussels-born directors and have been involved in the relatively small film company, Cobra Films, whose choice of projects shows a clear commitment to socially or culturally marginalised groups or individuals, particularly in Africa. The first film produced by Cobra films was Zaïre, maîtres des rues (Zaïre, masters of the streets, I989). In this documentary Dirk Dumon (scenario: Jean-Pierre Jacquemin) dealt with popular culture in Kinshasa's and Kisangani's public spaces, more particularly popular painting and new (Pentecostal, charismatic) churches. In this film one meets a relatively young, but already well-known Cheri Samba. The same directors recently wor- 
ked together as producers for the film Le Cercle des Noyés (Drowning in Oblivion, Cobra Films, 2006) about the victims of the I980's Mauritanian repression of the pro-black movement Forces de Libération Africaines de Mauritanie (African Liberation Forces of Mauritania). Sango Nini, quoi de neuf? (hereafter Sango Nini) claims to portray how people in Matonge "search continuously for their country through music, colors and words". Moreover, the release note specifies: "They live with us, they walk in our streets. They dream [behind] our walls. [and yet], our eyes rarely meet."

In evocative phrases such as these, it becomes clear that this film sees itself as dealing with a typical diasporic situation: a strong orientation of diasporic groups towards the home 'country' combined with a parallel, partly invisible existence elsewhere - to the extent of being considered 'out of place' or living a 'double absence' (Sayad I999). Such diasporic condition results, according to Clifford's well-known phrase, in "alternate public spheres, forms of community consciousness and solidarity that maintain identifications outside the national time/space in order to live inside, with a difference" (Clifford I994: 308).

\section{Changa-Changa, Rythmes en Noirs et Blancs (Mweze Ngangura, 1992)}

Mweze Dieudonné Ngangura is a Congolese filmmaker who has been based alternately in Zaïre/Congo and in Belgium since he finished art school in Brussels in 1975. He has made many films, short films and documentaries. His first documentary dates back to I980 and features Cheri Samba, who was then a young relatively unknown popular painter in Kinshasa. In I986 Ngangura made La vie est belle which starred the musician Papa Wemba - a collaboration which was repeated in his latest film Les habits neufs du Gouverneur (2006). In I998 Ngangura released his widely celebrated film Pieces d'Identité, about Congolese immigration to Belgium and partly situated in Matonge. In between both fiction films Ngangura made Changa-Changa, a documentary about the lively international, and above all intercultural music scene in Brussels from the late I950s onwards.

The film opens with scenes shot in Matonge in which Manu Dibango tries to locate the place of the now defunct music clubs Black and White and Les anges noirs (both located in the Stassaert street on the margins of present-day Matonge). For Dibango, these clubs were the places where music from Africa and 'black' music from the New World enjoyed each other's company and reached a mixed audience in late colonial Belgium and a rapidly decolonizing Brussels. in Changa Changa Ngangura presents this moment as the onset of the musical globalisation of Brussels/Belgium - a process which was carried on by the likes of Victor Lazlo, Khadja Nin, Zap Mama, and Toots Thielemans. One of the most remarkable aspects of Changa Changa is the cosmopolitan framing of (part of) Matonge in combination with the fact that he is marking Belgium's colonial projects in Africa as the origin of - what Abdoumaliq Simone (200I) would perhaps call - the 'worlding' of the metropole. 


\section{Matonge, un quartier africain au cœur de l'Europe (Patoma Gboya \& Abel Pulusu Homban, 2002)}

Both Abel Pulusu Homban and Patoma Gboya (alias Pat Patoma) are audio-visual entrepreneurs as well as journalists at a Brussels city radio station. The latter is called Radio Air Libre and caters for a number of special interest groups such as the gay and lesbian communities, the anti-globalisation movement, prisoners, anti-militarists, fans of different music genres (such as hiphop, chanson, and heavy metal), several language communities (Spanish and Portuguese, e.g.), and a number of regional communities (Latin-American, and indeed, also African) or a combination of the two, such as the Africa-related Lingala-spoken weekly programme Afrika Djamaa, for which Pulusu and Patoma both work. As the title indicates, the documentary Matonge, un quartier africain au cœur de l'Europe (hereafter Quartier africain) focuses on the spatial dimensions of the Matonge city neighbourhood in a number of quite dramatic episodes which predict nothing less than the imminent demise of the 'African quarter'. In addition, it strongly engages with the temporal dimension, the history of Matonge and, above all, the memories of those who have lived to see the African city quarter carve itself an urban space in a country in which Africans have remained generally speaking quite invisible. The central actors who embody respectively the beginning and the end of this time line are women - older women, some of whom set up their businesses in Matonge back in the I970s - and (male) youngsters. In the film the latter are somehow taken under the wings of both the women and the filmmakers in order to protect them against the allegedly false accusations voiced by local authorities and which typecast them as mere drug dealers and violent trouble makers.

\section{Juju Factory (2006 - Balufu Bakupa-Kanyinda)}

Balufu Bakupa-Kanyinda is a writer and filmmaker. He was born in Kinshasa but resided mainly outside the country after finishing his studies in Sociology, Philosophy and History in Brussels. Among his documentaries, Thomas Sankara (I99I) is one of his first while Afro@digital, a UNESCO-sponsored documentary on the digital revolution in Africa is among his more recent efforts. So far, Bakupa-Kanyinda has gained high praise for his film Le Damier (1996). This film is a captivating story of the surreal interactions between an African dictator-draughts player and his adversary, a simple, hungry and subaltern citoyen.

Juju Factory is a fiction film built around - what one critic called - a "kaleidoscopic narrative" about a writer named Congo Kongo (played by the late Dieudonné Kabongo) who sets out to write a book about Matonge, the Brussels town quarter where he lives with his wife. One of the other main characters is his tyrannical editor, Joseph Désiré - clearly referring to the late Zairian dictator Joseph Désiré Mobutu (I930-I997). In the film, the editor insists on Congo Kongo writing a light-hearted exotic travelogue entitled Matonge Village, while the writer gradually opts for a project and a book named Juju Factory. Both in its historical, psychological and conceptual scope, Juju Factory is more grand and sophisticated than the three other Matonge films. Above all, this film carries a heavy load of diasporic desires and anxieties. As the film maker explains himself, the idea of the film came during a trip to the slave castles Elmina in Ghana. This idea, objectified in the shape 
of juju, Bakupa-Kanyinda tells us, he brought to bear on the Matonge city quarter. The concrete Belgian past which the film brings into view harks back to I897 when around 250 Congolese men and women were shipped to Belgium to feature in the colonial section of the Universal exhibition, but the film also recalls the murder of Lumumba in I96I (see Couttenier 2005 and De Witte 1999, respectively). Psychologically and conceptually, the film maker displaces the diasporic 'double consciousness' and explores the multiplicity of attitudes and identifications of Congolese and Africans which he explicitly defines as 'in exile' in Belgium.

\section{Matonge as locus of postcolonial imagination and activism}

In this section I look into the four films as instances of the different ways in which 'Matonge' is a locus of postcolonial imagination and activism. Overall, I try to make the point that Matonge is not in any straightforward, natural, physical, or demographic way, a city quarter. Over time and in different discourses and practices, I argue, 'Matonge' emerges as a different thing altogether. In the analysis that follows, I distinguish between 'Matonge' (a) as a geographical 'point' of reference in an emerging discourse of diversity and emancipation, (b) as a 'place' (spatio-temporal unit) occupied by a community, and (c) as a 'site' of multiple identity formations and multi-scalar political activism. In each of these cases, I am interested in how references to, representations of, and interventions in the social and discursive space of 'Matonge', offer some insight into the changing postcolonial condition of Brussels/Belgium and into diasporic or exilic agency of Africans therein.

\section{The invention of Matonge as a geographical point of reference in an emerging discourse on cultural diversity and emancipation}

The Matonge that appears in Sango Nini, the oldest of the four films, is above all the city quarter that a small group of insiders recognise as the place of African/Congolese ambiance - reminding us that the I99os were the heyday of the SAPE (La Sociéte des Ambianceurs et des Personnes élégantes) movement (see Amponsah \& Spender 2003; Gondola 1999). This ambiance flourished largely under the radar of mainstream Brussels, in the relatively hidden Porte de Namur shopping mall and a number of clubs/cafés in its vicinity. It is important to point out that from the late I980s onwards this relative invisibility diminished rapidly.

The early I990s was a turning point in the founding of Matonge when it became the destination and place of contact of Africans/Congolese who were part of the post-Cold War 'new migration'. By then, the era of gradual immigration and partial return of students, merchants, etc. from Congo and a few other African countries, was largely over. Together with the rapid breakdown of what Abdelmalek Sayad (I999: II4) calls "the myth of the temporary and short-term nature of migration" people started to realise that hundreds of thousands of migrants residing in Belgian cities and towns were there to stay and were claiming a place in Belgian society.

Parallel to this recognition of the presence of a substantial migrant population residing in 
Belgium in the late I980s, one observes the rise of anti-migrant political parties (mainly in Flanders). Parallel with this, new institutions - such as the Koninklijk Commissariaat voor het Migrantenbeleid (KCM) - are created in order to monitor and manage migrant groups residing in Belgium, also in the hope of mitigating widespread anti-migrant feeling. At this stage, there was (and to a large extent still is) a rather ambivalent attitude according to which it is accepted that migrants be given full access to amenities such as schooling, housing, jobs, etc., but it proves more difficult to allow cultural diversity at least in the public sphere (Blommaert \& Verschueren I998; Arnaut, Ceuppens \& Delanote 2007).

In one passage of Sango Nini shows, the film makers try to address both the socio- economic and the cultural side of the acceptance of African migrants in Belgium, when they show the wife of a Congolese doctoral student in Brussels trying to find a flat. The passage is commented upon by an African 'griotic' voice-over (of the Congolese actor Maurice Boyikasse Buafomo.

The early nineties was the time when Africans, together with other European and nonEuropean migrant groups were slowly gaining visibility. This triggered recognition and appreciation by some Belgians, but contempt from others. Sango Nini clearly takes a positive attitude and generously expresses its cultural appreciation. One of the ways in which this is done is by foregrounding, so to speak, the voice-over, explicitly marking it as 'African', while granting the griot the privilege of announcing that 'nothing (scandalous) will be concealed'. This is the onset for revealing that African residents find it very difficult to gain access to the Belgian housing and job market. Thus, the griot and the film claim that Africans in Brussels - to paraphrase Virginia Woolf - deserve to earn money and a room of their own. The extent to which the filmmakers see the installation of Africans in Brussels in terms of multicultural juxtaposition or of intercultural collaboration, is difficult to make out. The least one can say is that (a) bits of both options are present in this newly emerging discourse concerning cultural diversity and the emancipation of minority groups, and that (b) 'Matonge' serves as a geographical point of reference in this emerging and at times rather ambiguous discourse (see Blommaert \& Verschueren i998).

In his own subtle way Ngangura in Changa Changa (I992) joins this emerging discourse by using 'Matonge' as a geographical reference point and springboard. One of his important contributions to the formation of this new discourse of diversity is that Ngangura adds a historical dimension which leads back to (late) colonial times. With the help of Manu Dibango, Ngangura asks attention for a short period of racial interaction and the breakdown of colonial barriers in the years preceding the independence of Congo. This intercultural renaissance is presented as one that was short-lived. It is in full swing in 1958 , the year of the World Exhibition and the foundation of 'Les Amis de Présence Africaine' bookshop and small conference centre near the Porte de Namur. Two years later this 'renaissance' comes to an end with the debacle of the decolonisation of Congo which results in the partial re- enclavation of Africans in Brussels (and the move of Dibango back to Africa and then to Paris). A further important element is that through the story about the nightclubs of the Stassaert street in which American, Caribean and 
African artists and music meet, the element of 'black' (diasporic) culture is brought in, indeed, never to disappear again as one of Matonge's key cultural components (see also Juju Factory).

In sum, in both documentaries Matonge is not so much presented as a place in its own right, but rather as a geographical point of reference for an emerging discourse of cosmopolitanism lost and (expectantly) refound, of postcolonial amnesia and misrecognition or at least disregard for cultural diversity and of the future presence and belonging of migrants in Belgian society.

\section{Matonge as a spatio-temporal unit or place occupied by a community}

As mentioned, the Matonge town quarter presented in the film Quartier africain, has definite borders, a history, and is populated/occupied by a community of Africans, represented (and reproduced) by women and youngsters. Arguably, this invention of Matonge as a proper place is the outcome of suffering or at least the perception/experience of suffering undergone by Africans and more often than not in and around Matonge.

Several authors have observed that victimisation can be a strong factor in processes of identity formation. In his seminal text on diaspora and identity, Gilroy (I997: 319) speaks of Afro-American "identity defined [...] by [...] histories of unspeakable suffering." (see also Broch-Due 2005: I9). In general one could say that the film constructs history, space, and community out of three aspects of this suffering: a history of repression (as Sango Nini has shown, still very present in the I990s), a present in which the boundaries of Matonge are under threat from property developers who serve the elites living in the upmarket zones bordering Matonge ('Louise' and 'Leopold'), and a future which is compromised by the fact that the youngsters of Matonge are discredited as unruly and indolent if not inherently violent and criminal.

Indeed, in the early 200os Matonge looked back on a distressing decade of bitter antagonism and a series of violent confrontations with the city council and the security forces (state and communal police). Simply stated, this was related to the arrival of migrants and city dwellers with a more precarious profile. These people (not in the least youngsters) faced an often defensive, if not inimical community of locals as well as offensive security forces. In the film, the defensive attitude of the locals is epitomized by that of the city council which at the time (late I990s) was led by a right-wing mayor (who is shown several times in the film).

The film indicates that these white elites reacted against the expansion of Matonge and thus the perceived 'Africanisation' of an erstwhile upper class white urban quarter. The hostile attitude of the security forces at that time involved them operating outside any schemes of dialogue or consultation, and seeing violent repression in the form of razzia's and other large-scale interventions, as the only adequate means of action. In the I99os, apart from youngsters, down-market shops and restaurants were also the target of city council inspection and retribution.

Moreover, from the year 2000 onwards, people in and around Matonge became more aware of this situation of suffering because in 2000 a new city council was elected and 
a left-wing coalition came into power. As is pointed out in the film at least twice, the new council effected a sea-change. One of its first projects was a quite radical change in dealing with the issue of Matonge by opting for collaboration, dialogue, joint projects of security, and of community policing. The official recognition that came with the creation of an official Matonge policy and of Matonge policing, went hand in hand with a large number of 'grassroots' and PPP-initiatives in which Matonge was said to show its potential and its positive qualities.

One passage from the film reminds us that the invention of Matonge as a proper or 'full' place or territory, is based on a trajectory of suffering which forms the basis for empowerment and the rejection of any paternalism or the infantilisation of Africans. The passage shows two instances of confrontations between Africans and white elites: first students versus the management of the Maison Africaine student house followed by confrontations between shop keepers and the major Yves De Jonghe d'Ardoie.

In a particularly trenchant way, these confrontations show the two faces of what is seen as the depreciation of African presence in Brussels, and Matonge. First the film confronts the current management of the Maison Africaine, which since the early rg6os has provided accommodation for Africans studying in Brussels. In the way the Maison Africaine is presented, one easily senses the colonial character also exhibited by the paternalist words of its manager. The passage on the Maison Africaine is immediately followed by a passage in which the negative judgements of the erstwhile mayor De Jonghe d'Ardoie are contradicted. Finally, both passages are commented upon by the same person, Kungu Luziamu, president of Interface Culture, and one of Matonge's main mediators/gate keepers. Through his voice the entire sequence appears as if the liberation from (neo)colonial paternalism is a source of empowerment for defying right-wing intolerance embodied by the former mayor.

Stated otherwise, the 'Matonge' of the early 2000 s portrayed in this film, seem to arise out of the debris of a long-overdue decolonisation of African-Belgian relationships, and of the repressive regime of the city council in the I990s. From this, Matonge emerges as a genuine place - a spatial unit with a history occupied by people who guarantee its reproduction, and in the process, makes a name ('Matonge') for itself.

It helps here to remind ourselves of what Doreen Massey said about the invention of what she calls "the coherence of a place": "The invention of tradition is here about the invention of the coherence of a place, about defining and naming it as a 'place' at all." (Massey 1995: I88). The 'place' called Matonge emerging here is very much the place in which Heatherington (I999) after de Certeau (I984) saw: "the capacity [...] to naturalize existing social relations and the ability of people to carve out spaces and moments of cultural engagement in which those relations could be recast and recontextualized." (Heatherington 1999: 316).

Perhaps not coincidentally, in 2002 - also the year the film was released - Matonge received the photographic blow up of the painting by Cheri Samba (Figure I). Put in the discourse of the film, this gigantic canvas was employed to display the name of Matonge, signal its vital existence, mark its territory and show its human capacity to whoever 


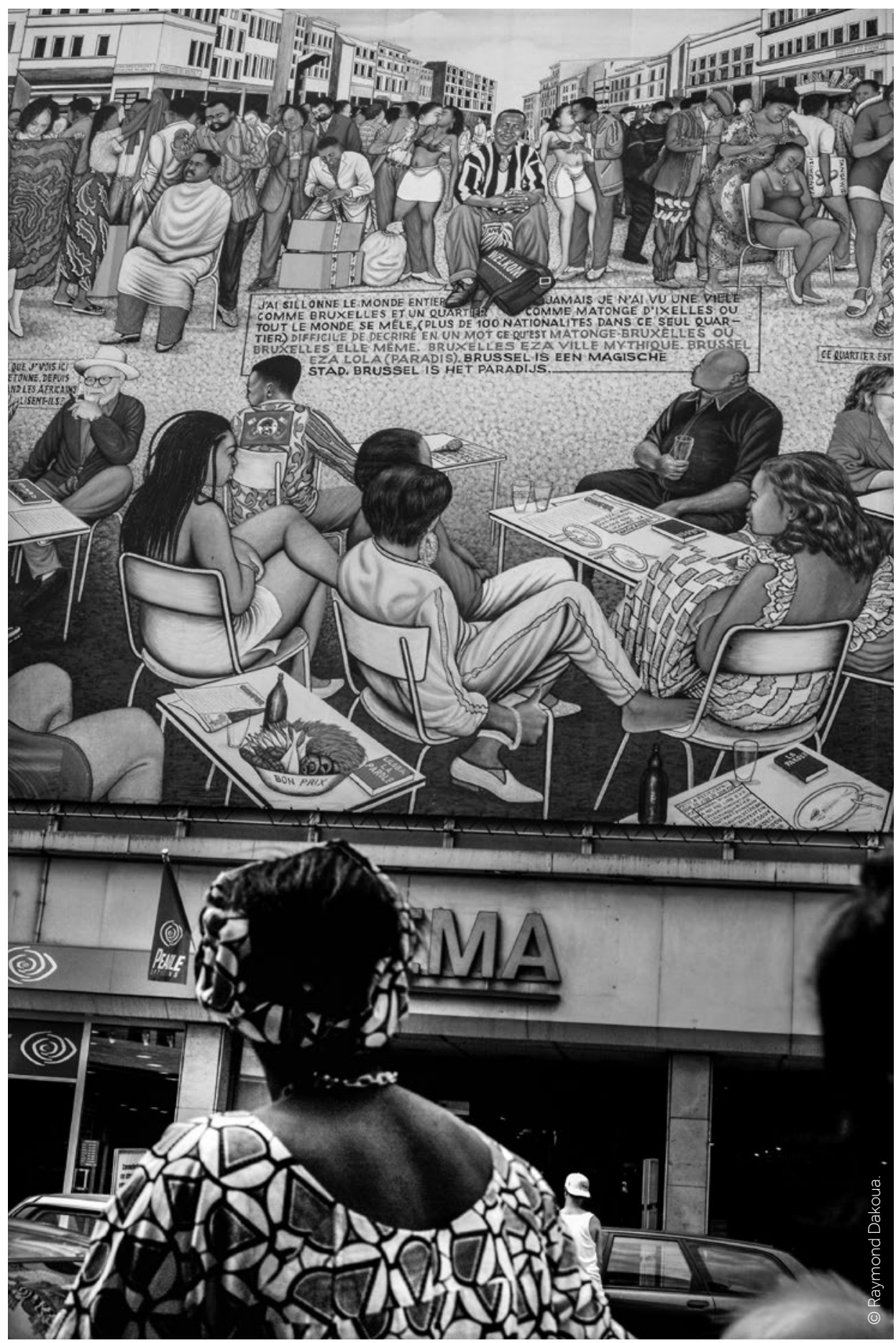

Figure 1: Photographic blow up of the painting by Cheri Samba in Matonge. 
approached it from the Brussels' city center. In the same year the makers of Quartier africain - to paraphrase Heatherington - carved out a named place called Matonge in recast Afro-Belgian relations which were suffering from both undeconstructed colonial attitudes and new-style post-Cold War intolerance and xenophobia.

\section{Matonge as a site of multiple identity formations and glocal alliances}

The 'Matonge' that appears in Juju Factory in 2006 is firmly established as a city quarter. By 2006 Matonge was enjoying official recognition from the different authorities that intervene in Brussels, that is, the Ixelles city council, the Brussels regional government and the governments of the Flemish and Francophone communities. Moreover these authorities found local and regional organisations ready to collaborate in manifold projects of multicultural emancipation and affirmation.

Since 200I Matonge has staged its annual feast Matonge en Couleurs/Matonge Gekleurd. The latter is organised with ample financial support from the Ixelles city council by an organisation called Interface Culture which is presided over by the Congolese cultural entrepreneur Kungu Luziamu - the voice-over in the film of Gboya and Homban. Interface Culture has the explicit goal of "promoting a positive image of the Matonge neighourhood". In 2004 Matonge also had a radio station called Radio Matonge that broadcasted intermittently. By 2006 Matonge proudly accommodated a socio- cultural centre Espace Matonge financed by the Brussels Capital Region (Ministry of Mobility) and a cultural shop Afrikamäli set up by the city council in collaboration with local commercial organisations. Soon also Matonge would have a 'Flemish-African House' funded by the Flemish Minister of Culture, Sport, Youth and Brussels Affairs.

In sum, in the years between the 2002 Matonge film and Juju Factory anno 2006, 'Matonge' had been officially recognized and to some extent institutionalized. Also it had its own marketable profile as "colourful", cosmopolitan, and exotic. With this official and commercial objectification Matonge emerged as a complex, multi-scalar space of identification and positioning (see Hall I990; Li 2000). This space comprised not only global relations such as those between Europe and Africa or between Belgium and DR Congo, but also subnational relations such as the ever problematic cohabitation of the Flemish and "French" (Francophone) Community in Belgium both of which have their say in matters of education and culture in the (officially bilingual) Brussels Capital Region. Some aspects of this institutionalised ethno-nationalist problematique can be found in a passage of Juju Factory in which an undocumented traveller - played by the anthropologist Ken Ndiaye, one of Matonge's most well-known residents, cultural entrepreneurs and, more recently, communal politicians - is arrested by the police. Much to the amazement of the (French-speaking) Ixelles' police, the 'illegal' migrant identifies as "a storyteller", and 'Dutch-speaking African'. A declaration which leads to his repatriation to South-Africa ("where Dutch is spoken").

Before we look into the matter of multi-scalar identification and positioning in this scene, let us first note the way in which Juju Factory deals with violence, repression and suffering the phenomenon that was thematised so strongly in Quartier africain and that was of central 
importance in the invention of Matonge as a 'place' in Sango Nini. In the excerpt the confrontation with the police of Ixelles is presented in two forms. First 'repression' is presented as 'real' in the 'reality-tv' type of footage from a grassroots film maker shooting images of how an undocumented fellow African is treated. Second, the historical despotism of the Mobutu era reappears in Juju Factory in the form of the dictatorial publisher Joseph Désiré. The latter's insistence on publishing only mellow and easily digestible literature, embodies market despotism. The way in which suffering is dealt with in this passage is rather typical of the way Balufu tells a multiplex narrative using a mix of genres and styles of narration. This opens up 'Matonge' as a complex space of identification and positioning in which the opposition between Flemish-Francophone is refracted.

The scene described above is by no means the only one in which the Flemish-Francophone opposition is presented. Brussels' bilingual predicament is personified by the central character of the film, the writer whose name is Kongo Congo. This oddly repetitive name is contextualised earlier in the film when the writer walks the streets of Brussels and repeatedly zooms in on the typical bilingual Brussels street signs, in one case, that of the "Rue Congo/Kongostraat". The larger picture is that, once recognized as a territorialized community, the Belgian-Africans cannot help but enter the complex play of Belgian communitarian politics. In this play of identification and positioning internal divisions within the African community are articulated in terms of pro-Flemish or proFrancophone stances.

During that same period one could witness several political articulations of this opposition. One instance of this has been the rise of strong anti-Kabila constituency in Belgium and Brussels. It accused former Belgian foreign secretary and then European commissioner Louis Michel, his fellow party member, then Minister of Development Cooperation, Armand De Decker of conspiring with president Kabila of DR Congo in order to continue the (neo-colonial) plundering of Congolese natural resources. Using the rhetoric of the Flemish economic success (see Ceuppens 20II), some anti-Kabila protesters had pleaded for closer Flemish-Congolese collaboration. This was recently documented by Bambi Ceuppens who interviewed Mariyus Noko Ngele, a Belgian-Congolese of the anti-Kabila movement who demands that Francophone Belgian politicians and entrepreneurs stay away from DR Congo. Moreover, he invites "the Flemish" to take the lead in a future Congo-Belgian economic union. The name of his movement is L'alliance des Réformateurs Kongolais. Needless to say the spelling of 'Kongolais' with a K can be seen as an attempt to emulate Flemish orthography and its preference for ' $k$ ' instead of ' $c$ ' (Ceuppens 2007; see also Arnaut 20II).

\section{In conclusion: three locations of postcolonial diaspora}

I set out to present how in a number of films Matonge emerges as a locus of postcolonial and diasporic imaginary and activism. Here I wish to spell out the different ways in which this 'locus' called Matonge brings out three dimensions of diaspora under conditions of postcoloniality.

In Sango Nini one finds most clearly represented what Safran (I991: 83) saw as one of the 
main conditions of diasporic communities, namely that "they believe that they are not [...] fully accepted by their host society and therefore feel partly alienated and insulated from it." Arguably, in Sango Nini this insulation is shown from within the 'host society' whose exclusionist attitude is revealed and deplored.

In Changa-Changa a similar voice is heard from a 'Gilroyan' in-between position (Gilroy 1995). Ngangura does not so much denounce the marginalisation of a half-hidden African 'parallel society' in the metropole, as he flaunts the diaspora's cultural authenticity and creativity as well as its saliency for the cosmopolitan music scene in a Brussels that globalises with the help of its former colony. Within the "alternate public spheres" (Clifford I994: 308) of diasporic communities, more particularly in the late colonial, parallel public sphere of 'black' nightlife and popular culture in Brussels, Ngangura situates the beginning of the musical globalisation of Belgium - perhaps a continuation of the gradual opening of the Black public sphere of the Harlem Renaissance in the United States. Quartier africain further thematises the emblematic diasporic theme of "...a shared history of displacement, suffering, adaptation, or resistance" in a process of "identification and differentiation" (Broch-Due 2005: I9). The sense of pan-Africanism that pervades this film is identified by Gilroy as one of the possible effects of diasporic identification: the fact that one easily forgets that "identity is the compound result of many accretions. [It] does not defer to the scripts of ethnic, national, 'racial' or cultural absolutism" (Gilroy I997: 323).

Without therefore abolishing the issues of historical suffering, present discrimination, or parallel lives, Juju Factory seems to transcend easy antagonisms and recomposes diasporic identities around the concept of 'exile' as de- and re-territorialisation. Although Gilroy (I997: 330) would perhaps not have chosen the word exile, the exilic identities in the film exemplify how diaspora "provides valuable cues, and clues for the elaboration of a social ecology of cultural identity and identification" (ibid: 332). Interestingly enough, in Gilroy's view 'exile' evacuates the complexity of "yearning and ambivalence" that resides in the concept of diaspora. 'Exile', for him implies a reconciliation either with the place of sojourn or with the place of origin, and this taming of diasporic subjects is accomplished when the nation-state disambiguates diasporic identities in a logic of either full inclusion or exclusion. Resignifying exile or diaspora for that matter in terms of de-territorialisation/re-territorialisation may help us move beyond the homogenous and monolithic nation-state, and face the fragmented nation-state called Belgium which Balufu encountered. With sharp irony Juju Factory evokes the complex multi-level governance of Belgium which finds its apex in the Brussels Capital Region where the federal government, the two languages communities, and the ig different communes share and divide power (see Favell \& Martiniello I999; Arnaut 2006). This multi-scalar governance situation offers a number of opportunities, particularly to the exilic or diasporic groups, Favell and Martiniello (I999: I9) argue:

'[The latter] have often found the cleavages and ethno-national conflicts inherent in the Brussels situation, and the institutional structure of city and communes useful to their goals; the declining role of the state in Brussels has helped free them to pur- 
sue economic and cultural activities which escape state control and regulation, and permit strong territorial ambitions in the city. Certain new activities and channels have thus become effective, and immigrant groups have been creative in reconfiguring their collective identities around the opportunities as presented, even connecting up on occasions with unlikely allies such as the Flemish right or the EU elite.' All this is put in a rather dramatic tone, but it basically boils down to prosaic processes of networking and alliance building in an ongoing process of positioning and identification as described by Hall (I990:30) when he alleges that: "cultural identities are the points of identification, the unstable points of identification or suture, which are made, within the discourses of history and culture. Not an essence but a positioning. Hence, there is always a politics of identity, a politics of position,...”.

This politics of position reveals what Cohen sees as the peculiarity of the relationship between diasporic groups and the nation state, namely that "for such diasporas the nation-state is being used instrumentally, rather than revered affectively" (Cohen I996: 5I8). Thus, Cohen (ibid.: 520) concludes "seen as a form of social organization, diasporas have predated the nation-state, lived uneasily within it and now may, in significant respects, transcend and succeed it." This is what the four Matonge films allegedly accomplish, mapping ways in which diasporas help metropoles to decolonize themselves.

\section{References}

Arnaut, Karel 2005. "Our Baka brothers obviously do not speak French": Siting and scaling physical/ discursive 'movements' in post-colonial Belgium. Language \& Communication 25 (3): 217- 235.

Arnaut, Karel 2006. Blowing bubbles in the city or does urban governance have a bad breath? Reports from Matonge, somewhere in Brussels. Aprior, December: 58-69.

Arnaut, Karel 20Ir. Reconfiguring (post)colonial space: The 'Manifestation for the re-annexation of Belgium to Congo'. In Art and activism in the age of globalization. L. De Cauter, R. De Roo, and K. Vanhaesebrouck, eds. Pp. I30-I39. Rotterdam: NAi publishers.

Arnaut, Ceuppens \& Delanote 2007. Voor de stad en voor de wereld: Interculturaliseren vanuit De Centrale: dromen en daden. Gent: Academia Press.

Blommaert Jan \& Jef Verschueren 1998. Debating Diversity: Analysing the Discourse of Tolerance. Londen: Routledge.

Broch-Due, Vigdis 2005. Violence and belonging: analytical reflections. In V. Broch-Due (Ed.)

Violence and belonging: the quest for identity in post-colonial Africa, pp. I-40. London: Routledge.

Ceuppens, Bambi 2007. Tout cela ne nous va pas rendre le Congo. Lecture given at Bozar, Brussels, 20 oktober 2007.

Ceuppens, Bambi 20Ir. From 'the Europe of the regions' to 'the European Champion League': the electoral appeal of populist autochthony discourses in Flanders. Social Anthropology I9(2):159-174.

Clifford, James 1994. Diasporas. Cultural Anthropology 9 (3): 302-338.

Cohen, Robin 1996. Diasporas and the nation-state: from victims to challengers. International affairs, 72 (3): 507-520.

Couttenier, Maarten. 2005. Congo tentoongesteld. Een geschiedenis van de Belgische antropologie en het museum van Tervuren (1882-1925). Leuven-Tervuren: Acco-KMMA. 
De Boeck, Filip 20I2. City on the move: How urban dwellers in Central Africa manage the siren's call of migration. In: The global horizon. Expectations of migration in Africa and the Middle East. K. Graw and S. Schielke, eds. Pp. 59-86. Leuven: Leuven University Press.

de Certeau, Michel 1984. The Practice of Everyday Life. Berkeley: University of California Press.

De Witte, Ludo. 1999. De moord op Lumumba. Leuven: Van Halewyck.

Favell, Adrian and Marco Martiniello 1999. Multi-national, multi-cultural and multi-levelled Brussels: national and ethnic politics in the 'Capital of Europe'. ESRC Transnational Communities Working Paper Series, No. WPTC-99-04.

Gilroy, Paul I995. Roots and routes: black identity as outernational project. In Racial and ethnic identity: psychological development and creative expression. H.W. Harris, H.C. Blue, and E.E.H. Griffith, eds. pp. I-I4. New York: Routledge.

Gilroy, Paul 1997. Diaspora and the detours of identity. In K. Woodward (ed.), Identity and Difference, pp. 299-345. London: Sage.

Gondola, Didier 1999. Dream and drama: the search for elegance among Congolese youth. African Studies Review, 42 (I): 23-48.

Hall, Stuart I99o. Cultural identity and diaspora. In: J. Rutherford (Ed.) Identity, community, culture, difference, pp. 222-237. London: Lawrence \& Wishart.

Heatherington, Tracey 1999 'Street tactics: Catholic ritual and the senses of the past in Central Sardinia', Ethnology, 38 (4): 315-334.

Li, Tania Murray 2000. Articultating indigenous identity in Indonesia: resource politics and the tribal slot. Comparative Studies in Society and History, 42 (I): I49-179.

Massey, Doreen 1992. Politics and space/time. New Left Review, I96: 65-84. Massey, Doreen I995. Places and their pasts. History Workshop Journal, 39: 182-192. Radio Matonge. http://www.noctis.com/ radiomatonge/lequartier.php

Ross, Marc Howard 200I. Psychocultural interpretations and dramas: identity dynamics in ethnic conflict. Political Psychology, 22 (I): 157-178.

Safran, William 199r. Diasporas in modern societies: myths of homeland and return. Diaspora I (I): $83-98$.

Sayad, Abdelmalek 1999. La double absence: des illusions de l'émigré aux souffrances de l'immigré. Paris: Seuil.

Shungu, Ekanga I986. L'Afrique noire à Bruxelles. Bruxelles: Les éditions européennes.

Simone, Abdoumaliq 200I. On the worlding of African cities. African Studies Review, 44(2): 15-4I. Werbner, Pnina 2002. Imagined diasporas among Manchester Muslims: the public performance of Pakistani transnational identity politics. Oxford: James Currey.

\section{Filmography}

Sango Nini, quoi de neuf?

I99I - Anne Deligne \& Daniel De Valck Changa-Changa, Rythmes en Noirs et Blancs I992 Mweze Ngangura

Matonge, un quartier africain au cœur de l'Europe 2002 - Patoma Gboya \& Pulusu Homban

Juju Factory 2006 - Balufu Bakupa-Kanyinda

The importance of being elegant 2003 - George Amponsah \& Cosima Spender, UK 